DOI: https://doi.org/10.32839/2304-5809/2021-11-99-8

УДК 347.73

Штогрін К.B. ${ }^{1}$

Інститут міжнародних відносин Київського національного університету імені Тараса Шевченка

\title{
ПРОБЛЕМИ ГАРМОНІЗАЦІЇ ЗАКОНОДАВСТВА УКРАЇНИ І ЄС У СФЕРІ БАНКІВСЬКОГО ПРАВА
}

\begin{abstract}
Анотація. Досліджено питання гармонізації законодавства України та ЄС у банківській сфері. Визначено, що програма гармонізації українського законодавства не відповідае сучасним напрямам розвитку банківського законодавства ЄС. Досліджено основні нормативно-правові акти, які визначають стратегію адаптації українського законодавства до права ЄС. Виокремлено задачі, які було частково виконано або не виконано у процесі гармонізації відповідно до нормативно-правових актів ЄС. Досліджено сучасний стан та прогрес імплементації угоди Базель III в СС та Україні і визначено подальші напрями співпраці. Виокремлено напрями майбутніх змін у банківському законодавстві ЄС на основі поточних тенденцій розвитку банківського сектору. Досліджено вплив цифровізації, технологій децентралізованих фінансів, криптовалют, цифрових валют на розвиток банківського законодавства.
\end{abstract}

Ключові слова: ЄС, банк, банківське законодавство, європейська інтеграція, гармонізація, Базель III, криптовалюти, цифровізація.

Shtogrin Kyryl Institute of International Relations Taras Shevchenko National University of Kyiv

\section{PROBLEMS OF HARMONIZATION OF UKRAINIAN AND EU LEGISLATION IN THE FIELD OF BANKING LAW}

Summary. The issue of harmonization of the legislation of Ukraine and the EU in the banking field is investigated. It is determined that the program of harmonization of Ukrainian legislation does not correspond to modern directions of development of EU banking law. The main legal and regulatory instruments that determine the strategy of adaptation of Ukrainian legislation to EU law are studied. It is found that Ukraine has undertaken a wide range of commitments to adapt banking legislation, which are being implemented relatively slowly. The tasks that have been partially fulfilled or not fulfilled in the process of harmonization in accordance with EU regulations are highlighted. Important areas of harmonization remain the implementation of the provisions of Directive 2001/24/EU, Directive 2014/59/EU, Directive 2014/49/EU, Directive 2015/2366, Regulation 575/2013. The current state and progress of the implementation of the Basel III agreement in the EU and Ukraine are studied and further areas of cooperation are identified. It is determined that the EU in October 2021 completed the implementation of the Basel III agreement. It is determined that Ukraine is in the process of the implementation of the agreement in accordance with the Strategy of Ukrainian financial sector development until 2025. The directions of future changes in the EU banking law are highlighted based on current trends in the development of the banking sector. The influence of digitalization, technologies of decentralized finance, cryptocurrencies, digital currencies, which form new configurations of mechanisms for providing traditional banking services, on the development of banking law has been studied. It is determined that these trends put pressure on the traditional business models of banking. It is determined that financial intermediaries will have to fundamentally rethink their roles and business models in the new financial systems. The latest EU legislative initiatives are highlighted, namely: Digital Markets Act, Digital Services Act, Markets in Crypto Assets Regulation, revision of the Payment Services Directive, regulation of the use of artificial intelligence technologies in banking, Regulation on the single digital currency. It is proposed to incorporate the directions of future development of the EU banking law into the Association Agreement between Ukraine and the EU in case of its revision.

Keywords: EU, bank, banking legislation, European integration, harmonization, Basel III, cryptocurrencies, digitalization.

$\prod \begin{aligned} & \text { остановка проблеми. } \mathrm{y} \\ & \text { Україна визначила основною метою сво- }\end{aligned}$ єї зовнішньої політики поглиблення інтеграції з Свропейським Союзом і подальше входження до ЄС у якості їі держави-члена. У тому ж році було підписано Угоду про асоціацію між Україною, з однієї сторони, та Свропейським Союзом, Свропейським співтовариством з атомної енергї і їхніми державами-членами, 3 іншої сторони. 3 метою виконання положень Угоди про асоціацію Україна зобов'язалась, у тому числі, гармонізувати свое законодавство із законодавством
ЄС у різних напрямах. Одним з таких напрямів стала система банківського права України. Проте після семи років, які минули з моменту підписання Угоди про асоціацію, Україна стикнулася з низкою викликів. У европейському законодавстві щодо банків, банківської діяльності, банківського нагляду та регулювання відбулися значні зміни. Через це переважна частина нормативноправових актів ЄС, які згадані в тексті Угоди, а саме у Додатку XVII Угоди про асоціацію, було скасовано, замінено новими актами законодавства або до них було внесено зміни. У результаті,

${ }^{1}$ ORCID: https://orcid.org/0000-0002-7431-9810

(C) Штогрін К.В., 2021 
програма гармонізащї українського законодавства у банківській сфрері, закладена в Угоді про асоціацію, не відповідає сучасним напрямам розвитку банківського законодавства ЄC.

Аналіз останніх досліджень і публікацій. Питанню гармонізації банківського законодавства України та ЄС присвячені роботи та дослідження таких українських вчених, як: О.А. Музика-Стефранчук, Д.О. Гетьманцев, Н.Л. Губерська, H.M. Ковалко, В.I. Муравйов, О.І. Виговський, Б.М. Криволапов, М.М. Король, В.Г. Савенкова та інші. Питання розвитку європейського банківського права було висвітлено в роботах таких зарубіжних науковців, як Д. Альфорд, А. Банд, Д. Крістополус, А. Годвін, І. Рамзі, Р. Гоял, С. Хомбург, П. Хютль, А. Керн, Д. Шонмейкер, Дж. Кремерс, Л. Леві, Д. Шедрер, Дж. Вестергард та інші.

Виділення не вирішених раніше частин загальної проблеми. Сdpepa банківської діяльності характеризуеться стрімкою динамікою свого розвитку, а тому відповідні зміни у законодавстві, що її регулюе, необхідно постійно відслідковувати. Крім того, за останні декілька років Україна зробила значний прогрес у адаптації своєї нормативно-правової бази у банківській copepi до стандартів та вимог ЄС. Отже виникає потреба дослідити сучасні тенденції розвитку банківського законодавства СС, а також виокремити проблемні напрями, 3 якими стикаеться Україна при здійсненні гармонізації законодавства, та визначити перспективи і майбутні напрями співпращі.

Мета статті. Головною метою ціеї роботи $є$ ідентифікація проблем та викликів гармонізації законодавства України і СС у банківській сррері на основі вивчення чинного законодавства України і ЄС та узагальнення практики їх реалізації.

Виклад основного матеріалу. У 2014 році Україна підписала Угоду про асоціацію між Україною, з одніеї сторони, та Свропейським Союзом, Свропейським співтовариством з атомної енергії і їхніми державами-членами, з іншої сторони (далі - Угода про асоціацію) [6]. 25 жовтня 2017 року Кабінет Міністрів України ухвалив постанову № 1106 «Про виконання Угоди про асоціацію між Україною, з одніеї сторони, та Європейським Союзом, Свропейським співтовариством 3 атомної енергії і їхніми державами-членами, з іншої сторони», яка передбачає виконання плану заходів з гармонізації українського законодавства [1]. У сфрері гармонізації законодавства у банківській сфрері, Планом заходів передбачається імплементація міжнародних стандартів та актів ЄC щодо запобігання відмиванню грошей та фрінансуванню тероризму, впровадження принципів ефрективного банківського нагляду Базельського комітету, запровадження вимог щодо внутрішньої оцінки достатності капіталу банку (ICAAP), приведення у відповідність з правом ЄС вимог до структури капіталу банків тощо [1]. Наразі основним документом у сфері гармонізації банківського права, який визначае "дорожню карту» реалізації положень Угоди про асоціацію у банківській cфpepi виступає Стратегія розвитку фінансового сектору України до 2025 року [5].

Зобов'язання, які взяла на себе Україна, у частині адаптації свого законодавства до нормативно-правових актів ЄС, містять широкий обсяг необхідних змін, а саме зміни у сфері банківської діяльності, страхової діяльності, фрункціонування ринків цінних паперів, фрункціонування ринків капіталу, платіжних послуг, запобігання відмиванню грошей та фінансуванню тероризму, лібералізації руху капіталу та руху валют [7]. Необхідно підкреслити, що процес адаптації українського законодавства йде порівняно повільно. Як зазначаеться у системі моніторингу реалізації плану заходів з виконання Угоди про асоціацію між Україною та ЄС, що загальний прогрес гармонізації законодавства України та ЄC у фрінансовому секторі складає $57 \%$ у період з 01.11.2014 року по 31.10.2024 року та лише $24 \%$ у напрямі фрінансового співробітництва та боротьби з шахрайством [2]. Зокрема у банківській сфрері було частково виконано або не виконано наступні задачі, наприклад [2]:

- відповідно до Директиви 2001/24/€С та Директиви 2014/59/СС Фонд гарантування вкладів фрізичних осіб, Національний банк України та Міністерство фрінансів України мають удосконалити процедури оздоровлення та виведення банків з ринку;

- відповідно до Директиви 2014/49/СС Фонд гарантування вкладів фрізичних осіб, Національний банк України та Міністерство фрінансів України мають привести порядок відшкодування вкладів у відповідність із правом ЄС. Наразі на розгляді у Верховній Раді України перебуває законопроєкт № 5542-1 «Про внесення змін до деяких законів України щодо забезпечення стабільності системи гарантування вкладів фрізичних осіб», яким, зокрема, буде збільшено суму гарантування вкладів фрізичних осіб до 600 тис. гривень до 2023 року. 30 червня 2021 Верховна Рада України у першому читанні прийняла законопроєкт № 5542-1;

- згідно з Директивою 2014/49/ЄС Фонд гарантування вкладів фрізичних осіб, Національний банк України та Міністерство фрінансів України мають, зокрема, удосконалити пруденційні вимоги та нагляд за діяльністю кредитних спілок та запровадити обов'язкову участь кредитних спілок у системі гарантування вкладів. 1 червня 2021 року Верховна Рада України у першому читанні прийняла законопроєкт № 5125 «Про кредитні спілки». Зазначене питання також буде регулюватися законпроєктами «Про страхування» і «Про фрінансові послуги та фрінансові компанії»;

- відповідно до Регламенту 575/2013 Національний банк України має запровадити нові вимоги щодо показника левериджу та удосконалити вимоги до значної концентрації кредитного ризику;

- згідно 3 Директивою 2015/2366 Національний банк України та Міністерство фрінансів України мають виконати низку задач у сырері регулювання ринку платіжних послуг. 30 червня 2021 року Верховна Рада України прийняла Закон України «Про платіжні послуги». Проте наразі Національний банк України має розробити та видати низку нормативно-правових актів, які стосуватимуться вимог до капіталу надавачів платіжних послуг, визначення умов надання платіжних послуг, порядку авторизації надавачів платіжних послуг тощо [2].

Варто вказати, що у березні 2021 року Національний банк України, Національний банк 
Польщі та Банк Литви уклали угоду про реалізацію проекту «Twinning», який має допомогти НБУ, серед іншого, імплементувати Угоду про асоціацію між Україною та ЄС. Передбачається співпраця у розвитку підходів до банківського нагляду шляхом подальшої імплементації принципів банківського нагляду Базельського комітету, запровадженні системи миттєвих платежів, удосконаленні механізмів стратегічного планування, европейської інтеграції та міжнародного співробітництва [4].

Необхідно підкреслити, що Планом заходів передбачається не лише імплементація нормативно-правових актів ЄС, а й імплементація міжнародних стандартів та рекомендацій. Одним 3 таких зобов'язань $є$ впровадження принципів ефрективного банківського нагляду Базельського комітету. Світова фрінансова криза 2007-2008 років виявила багато недоліків в нормативних вимогах щодо ліквідності банків Північної Америки та Європейського Союзу та призвела до запровадження у грудні 2010 року Базельським комітетом 3 банківського нагляду оновлених рекомендацій у сорера банківського регулювання, який називається Базель III, остаточний перехід до якого був запланований протягом 2012-2019 років. Основні етапи реалізації Базельської угоди Базельським комітетом 3 банківського нагляду полягали у запровадженні нових вимог до коефіціентів левериджу, буферів капіталу, коедіцієнтів покриття ліквідності тощо [16]. У ЄС зміст угоди зміст Базель III було включено до двох нормативно-правових актів $\mathrm{CC:}$

- Регламент (СС) 575/2013 від 26 червня 2013 року (CRR), який регулює вимоги щодо пруденційного нагляду за першим компонентом («Pillar 1») та вимоги до публічного розкриття інформації за третім компонентом («Pillar 3») [17];

- Директива 2013/36/ЄC від 26 червня 2013 року (CRD IV), яка, серед іншого, стосуеться доступу до діяльності кредитних установ, свободи заснування, свободи надання послуг, процесів наглядової перевірки та додаткових резерви власного капіталу [8].

27 жовтня 2021 року Свропейська Комісія ЄС ухвалила рішення про прийняття пакету доповнень до системи банківських правил СС (Регламент про вимоги до капіталу та Директива про вимоги до капіталу для галузі фрінансових послуг). Ці нові правила гарантують, що банки ЄС стануть більш стійкими до потенщійних майбутніх економічних потрясінь, водночас сприяючи відновленню країн Свропи від наслідків пандемії COVID-19 та переходу до кліматичної нейтральності [9]. Цей пакет нормативно-правових актів завершує імплементацію угоди Базель III в ЄС. Пакет доповнень складається з наступних нормативно-правових елементів [9]:

- пропозиція щодо внесення змін до Директиви про вимоги до капіталу для галузі фрінансових послуг (Директива 2013/36/СС);

- пропозиція щодо внесення змін до Регламенту про вимоги до капіталу (Регламент 2013/575/СС);

- окрема пропозиція щодо внесення змін до Регламенту про вимоги до капіталу у сфрері санації (так звана пропозиція «гірлянди»/«ланцюга»).

Пакет доповнень складається 3 наступних частин [9]:
1. Впровадження Базеля III та посилення стійкості до еконолічних потрясінь. Пакет доповнень реалізуе міжнародну угоду Базель III, враховуючи при цьому особливості банківського сектору СC, наприклад, у частині іпотечного кредитування 3 низьким рівнем ризику. Зокрема, пакет спрямований на те, щоб внутрішні моделі, які використовуються банками для розрахунку вимог до капіталу, не занижували ризики, забезпечуючи тим самим достатній рівень капіталу, необхідний для покриття цих ризиків. У свою чергу, це спростить порівняння коефіціентів капіталу на основі ризику між банками, відновивши довіру до цих коедріщієнтів та стабільність фрінансового сектора в цілому. Пакет пропозицій спрямований на посилення стійкості банківського сектору, не призводячи при цьому до значного збільшення вимог до капіталу. Це обмежуе загальний вплив на вимоги до капіталу на мінімально необхідному рівні, що дозволить підтримувати конкурентоспроможність банківського сектору ЄC. Пакет доповнень також зменшуе витрати на виконання вимог, зокрема для малих та середніх банків, без послаблення пруденційних стандартів [11].

2. Сталий розвиток та "зелений» перехід. Посилення стійкості банківського сектору до екологічних, соціальних та управлінських ризиків (ESG) є ключовою сферою Стратегії Свропейської Комісії зі сталого фінансування. Для Свропейської Комісії було важливо законодавчо закріпити способи вимірювання банками цих ризиків і управління цими ризиками, а також забезпечити те, щоб фінансові ринки могли самостійно контролювати діяльність банків. У цьому відношенні вирішальну роль відіграє пруденційне регулювання. Пакет пропозицій вимагатиме від банків систематичного визначення, розкриття та управління ризиками ESG як частини їхньої системи управління ризиками. Це включає регулярні «кліматичні» (екологічні) стрес-тестування як органами банківського нагляду, так і банками. Наглядові органи повинні будуть оцінювати ризики ESG як обов'язкову частину регулярного банківського нагляду. Усі банки також повинні будуть розкривати ступінь впливу на них ризиків ESG. Щоб уникнути невиправданого адміністративного тягаря для малих та середніх банків, правила розкриття інформації будуть пропорційними. Запропоновані заходи не тільки зроблять банківський сектор більш фінансово стійким, але й забезпечать врахування банками міркувань екологічної стійкості $[11 ; 12]$.

3. Посилений банківський нагляд, забезпечення надійного управління банкали ЄC, краший захист ббінансової стабільності. Пакет доповнень надає більш потужні інструменти для наглядових органів, які контролюють банки ЄС. Він встановлює чіткий, надійний і збалансований набір правил, за яким банківські наглядові органи оцінюють, чи має менеджмент банку необхідні навички та знання для управління банківською структурою. Більше того, у відповідь на скандал, який відбувся 3 фонінех-компанією «WireCard», банківські наглядові органи ЄС тепер отримають більш дієві інструменти для нагляду за фрінтех-компаніями, включаючи компанії, афрілійовані з банками. Цей розширений набір інструментів забезпечить надійне та виважене управління банками 
ЄС. Пакет доповнень також розглядає питання створення фрілій банків третіх країн у СС. Наразі ця сорера переважно підпадає під дію національного законодавства кожної держави-члена $\mathrm{CC}$, яке гармонізоване лише в дуже обмеженій мірі. Пакет узгоджуе правила ЄC у цій сфpepi, що дозволить органам банківського нагляду краще керувати ризиками, пов'язаними з цими тіньовими банківськими суб'єктами, які за останні роки значно активізували свою діяльність в СС [9].

На відміну від країн СC реалізація рекомендацій Базель III Національним банком України була розпочата лише у 2015 році, а відповідно, завершення цього процесу в Україні планувалося до 2020 року, проте досі частини цих положень продовжують імплементуватися,. НБУ розпочав впровадження Базель III у рамках Комплексної програми розвитку фінансового сектору України на 2020 рік, прийнятої НБУ у 2015 рощі («Програма 2020»). Програма 2020 була доповнена рішенням Правління НБУ від 05.04.2017 № 207рш «Про затвердження планів імплементації законодавства ЄС на виконання Угоди про асоціацію» [3].

Відповідно до Програми-2020 НБУ впроваджує Базельські стандарти у якості бази для створення передумов сталого, інклюзивного розвитку фінансового сектору України. Варто зазначити, що НБУ обрав підхід поступового впровадження нових вимог з метою запобігання утворенню негативних наслідків та забезпечення необхідного часового проміжку для банківських установ для коригування своїх бізнес-моделей і виконання нових вимог законодавства. Більше того, НБУ наголосив, що деякі з вимог угоди Базель III не можуть бути впроваджені в Україні через їх високу складність для вітчизняної банківської системи.

Наразі Комплексна програма розвитку фpiнансового сектору України на 2020 рік отримала своє продовження у вигляді Стратегії розвитку фінансового сектору України до 2025 року від 16 січня 2020 року [5]. У 2017 рощі НБУ вказував, що розробка всіх нормативно-правових актів щодо угоди Базель III мала бути завершена до 2020 року, проте процес імплементації угоди Базель III досі не є завершеним [5; 16]. Варто відмітити, що процес імплементації угоди Базель III позитивно вплинув на стан банківського сектору України, зокрема, зменшилась кількість проблемних (збиткових) банків, скоротилася зовнішня заборгованість банків тощо.

Проте Україні при визначенні напряму розвитку свого законодавства у банківській сфрері також варто звертати увагу на ті тенденції, які будуть визначати майбутне банківської сорери ЄС. Цифрровізація фрінансів та фрінансових послуг призвела до появи у сырері фрінансів нових регуляторних нормативно-правових актів по всьому світу, у тому числі у СС. Необанки або банки-челленджери та фрінтех-компанії, що спеціалізуються на одній чи кількох конкретних фрінансових або банківських послугах, один за іншим системно редормують банківські ринки. Яскравими прикладами можуть слугувати послуги, пов'язані 3 онлайн-платежами, онлайн-покупками частинами або фрінансування оборотних коштів. Великі технологічні компанії, такі як «Фейсбук», «Еппл», «Амазон» та інші, інтегрують платіжні послуги у свої платформи, i, очікується, що слідом за ними буде включатися все більше банківських послуг. Криптовалюти та технологї децентралізованих фрінансів формують нові конфрігурації механізмів надання традищійних банківських послуг. Хоча деякі дослідники вважають, що фрінансові посередники, такі як банки, можуть стати зайвими у новому цифровому світі, де домінують технології, більш розповсюдженою є думка, що фрінансовим посередникам доведеться фрундаментально переосмислити свої ролі та бізнес-моделі у нових фінансових системах [10].

Сучасними «цифровими» законодавчими проблемами, які безпосередньо пов'язані з банківською діяльністю, виступають обмін даними користувачів банківських послуг, цифрова ідентифікація та верифікація, криптовалюти та цифровий євро. Спільним у цих проблем є те, що вони, кожна по-своєму, ставлять під тиск традиційну банківську бізнес-модель. Наразі Свропейська Комісія працюе над кількома ініціативами, пов'язаними 3 банківськими та іншими фрінансовими даними, включаючи регулювання використання технологій штучного інтелекту у банківській діяльності, перегляд Директиви про платіжні послуги, створення єдиного нормативно-правового акту про дані. Крім того, 3 кінця 2020 року на розгляді у Свропейському парламенті знаходять проекти Закону про цифрові ринки (Digital Markets Act, DMA) та Закону про цифрові послуги (Digital Services Act, DSA), які містять положення про регулювання окремих видів банківських та фрінансових послуг у цифровому просторі $[10 ; 13 ; 14]$. У зв'язку з цим необхідно згадати ще одну регуляторну ініціативу Свропейської Комісії, а саме пропозищію створити европейську систему цифррової ідентифрікації та верифікації. Мета - запровадити цифровий гаманець для громадян, у якому зберігатимуться їхні цифрові документи та інша особиста інформація. Потім за потреби цими даними можна поділитися з постачальниками цифрових послуг по всьому ЄС. Таким чином, гаманець має стати єдиним ключем доступу до цифрових ринків.

Ще однією сорерою, яка стрімко розвивається і підлягає регулювання банківським законодавством, - це криптовалюти та технології децентралізованих фінансів. Безсумнівно, завдяки стабільно низьким або від'ємним процентним ставкам і високим індексам фондових ринків, інтерес до криптоактивів серед кліентів банків (як роздрібних, так і оптових) зріс за останні декілька років. 3 точки зору регулювання ключовим питанням $є$ те, що банківське регулювання та банківський нагляд побудовані навколо відповідних суб'єктів банківської діяльності. Ліцензї видаються зареєстрованим підприемствам, а нагляд здійснюеться за суб’єктами, за якими можна здійснювати фізичний нагляд, на які можна накладати штрафри або на які можна подавати до суду у випадку невиконання регуляторних вимог. Децентралізовані фрінансові платформи 3 відкритим вихідним кодом, які не належить певному підприємству чи фрізичній особі, і працюють на децентралізованій технології блокчейну, не відповідають зазначеному підходу, заснованому на суб'єктності учасників фінансових ринків. Наразі відсутні регуляторні механізми ліцензування, штрафрування або закриття відкритих де- 
централізованих платформ, оскільки відсутній суб'єкт регулювання, окрім кожного окремого користувача, який запускає таке програмне забезпечення для здійснення фрінансових операцій. Наразі Європейська Комісія розглядає проєкт Регламенту про ринки криптоактивів («Markets in Crypto Assets Regulation», MiCAR), у той час як Базельський комітет розглядає пруденційне регулювання криптоактивів на балансах банківських установ [15]. Необхідність чіткого визначення регуляторних вимог, будь-то з точки зору захисту прав споживачів банківських послуг, підтримання стабільності фінансових ринків або пруденційного нагляду, є ключовою передумовою для регульованих фрінансових установ для подальших кроків у їх операціях 3 криптоактивами, криптовалютами з використанням децентралізованих фрінансових систем.

Іншим, складним для врегулювання питанням постає циоровий євро, тобто варіант роздрібної цифрової валюти центрального банку для ЄС. Лише три-чотири роки тому цифрові нащіональні валюти були надзвичайно вузькою темою, і більшість центральних банків відносилися до неї як до абстракції як з технологічної, так і з регуляторної точки зору. Все змінилося, коли декілька великих технологічних компаній оголосили про запуск своїх власних цифррових валют, а центральний банк Китаю почав проводити фрізичні випробування використання цифрового юаню. Сьогодні вже $36 \%$ центральних банків країн світу, які охоплюють $74 \%$ світового населення, розглядають питання запровадження цифрової валюти [10]. Свропейська Комісія хоче запобігти тому, щоб криптовалюти великих технологічних компаній або криптовалюти деноміновані у валютах, інші ніж євро, взяли на себе роль основної валюти в повсякденному житті громадян СС, оскільки це погіршить здатність Свропейського центрального банку керувати економікою за допомогою грошово-кредитної політики. Випуск технологічними компаніями власних криптовалют також може створити небезпечні ситуації 3 утворенням неконтрольованих державою dpiнансових екосистем. Тим не менш, европейські законодавці намагаються сприяти відкриттю та прозорості таких фінансових екосистем, наприклад, шляхом спрощення та підвищення ефрективності обміну фрінансовою та банківською інформацією та особистими даними. Сдиними прийнятним варіантом для СС є випуск власної цифрової валюти, ніж домінування у банківській та фінансовій системах ЄС кількох неконтрольованих криптовалют багатонаціональних підприємств. На початку 2023 року Свропейська Ко- місія має прийняти Регламент, в якому будуть викладені ключові особливості запровадження та використання єдиної цифрової валюти. Таким чином, у найближчі 18 місяців будуть прийняті важливі рішення, i буде визначати, чи виявиться цифровий евро корисним для банків та банківської діяльності, чи натомість він насамперед послабить позиції банків у порівнянні з великими технологічними компаніями, які безперешкодно інкорпорують цифровий євро у свої екосистеми.

Висновки. У процесі імплементації положень Угоди про асоціацію Україна стикнулася 3 тим, що европейське законодавство у сорері банківської діяльності перебуває у процесі динамічного оновлення, яке стало відповіддю на поставлені перед інтеграційними процесами у ЄC викликами. Зобов'язання, які взяла на себе Україна, містять широкий обсяг необхідних змін, а тому, відповідно, загальний прогрес гармонізації законодавства України та СС відбувається порівняно повільно із запланованими на момент підписання термінами. Важливими напрямами гармонізації залишаються виконання положень Директиви 2001/24/СС, Директиви 2014/59/ЄC, Директиви 2014/49/ЄС, Директиви 2015/2366, Регламенту 575/2013 тощо. Одним з основних напрямів також виступає впровадження принципів ефективного банківського нагляду Базельського комітету, яке розпочалося у 2015 році. У жовтні 2021 року ЄC ухвалив фінальний пакет доповнень до системи банківських правил, яким завершив імплементацію угоди Базель III. В свою чергу, Україна поки продовжує імплементацію угоди відповідно до Стратегії розвитку фінансового сектору України до 2025 року. Загалом, законодавство у банківській сорері має бути динамічним, щоб встигнути за останніми тенденціями на ринках банківських послуг і банківських продуктів. Можна визначити декілька напрямів, які будуть визначати майбутню динаміку змін: цифрровізація банків і банківських послуг, виникнення необанків або банків-челленджерів, посилення ролі фрінтех-компаній у банківському середовищі, зростання частки онлайн-платежів, зростання частки онлайн-покупок, посилення ролі криптовалют та криптоактивів, розвиток децентралізованих фрінансів, цифрова ідентифікація та верифікація, цифровий евро. Ці тенденції визначають майбутні зміни у банківському праві: Закон про цифррові ринки СС, Закон про цифрові послуги ЄС, Регламент про ринки криптоактивів СС тощо. Важливо зазначити, що ці напрями майбутнього розвитку законодавства мають знайти своє відображення в Угоді про асоціацію між Україною та ЄС у випадку її оновлення.

\section{Список літератури:}

1. Кабінет Міністрів України. Постанова від 25 жовтня 2017 р. № 1106 «Про виконання Угоди про асоціацію між Україною, з одніеї сторони, та Європейським Союзом, Європейським співтовариством з атомної енергії i їхніми державами-членами, з іншої сторони». URL: https://zakon.rada.gov.ua/laws/show/1106-2017-п\#Text

2. Кабінет Міністрів України. Система моніторингу виконання Угоди про асоціацію між Україною та ЄС. Iнформаційно-аналітична система «Пульс Угоди». URL: http://pulse.eu-ua.org

3. Національний банк України. Рішення Правління НБУ «Про затвердження планів імплементації законодавства ЄС на виконання Угоди про асоціацію» від 05.04.2017 № 207рш.

4. Національний банк України. Центробанки Польщі та Литви допоможуть Національному банку України імплементувати Угоду про асоціацію між Україною та ЄC. 2021. URL: https://bank.gov.ua/ua/news/all/ tsentrobanki-polschi-ta-litvi-dopomojut-natsionalnomu-banku-ukrayini-implementuvati-ugodu-pro-asotsiatsiyu-mij-ukrayinoyu-ta-yes 
5. Стратегія розвитку фрінансового сектору України до 2025 року. Національний банк України. 2020. URL: https://bank.gov.ua/admin_uploads/article/Strategy_FS_2025.pdf?v=4

6. Угода про асоціацію між Україною, з однієї сторони, та Європейським Союзом, Європейським співтовариством з атомної енергії і їхніми державами-членами, з іншої сторони. URL: https://zakon.rada.gov.ua/laws/ show/984_011\#Text

7. Центр Разумкова. Секторальна інтеграція України до ЄС: передумови, перспективи, виклики. Київ, 2020. URL: https://razumkov.org.ua/uploads/article/2021_sektor_eu_ukr.pdf

8. Directive 2013/36/EU of the European Parliament and of the Council of 26 June 2013 on access to the activity of credit institutions and the prudential supervision of credit institutions and investment firms dated 28/06/2021. URL: http://data.europa.eu/eli/dir/2013/36/oj

9. European Commission. Press release. Banking Package 2021: new EU rules to strengthen banks' resilience and better prepare for the future. Brussels, 2021.

10. ING Bank. Bank sector outlook 2022: Bracing for transformation. 2021. URL: https://think.ing.com/articles/ bank-sector-outlook-2022-bracing-for-transformation/

11. Intesa SanPaolo. Basel III, Pillar 3. Disclosure as of 30 September 2019. 2019.

12. Moloney N. European Banking Union: assessing its risks and resilience. Common Market Law Review. 2014. T. 51. № 6 .

13. Proposal for a regulation of the European parliament and of the council on contestable and fair markets in the digital sector (Digital Markets Act). COM/2020/842 final dated 15.12.2020.

14. Proposal for a regulation of the European parliament and of the council on a Single Market for Digital Services (Digital Services Act) and amending Directive 2000/31/EC. COM/2020/825 final dated 15.12.2020.

15. Proposal for a regulation of the European parliament and of the council on Markets in Crypto-assets and amending Directive (EU) 2019/1937. COM/2020/593 final dated 24.09.2020.

16. Ramskyi A. et al. Integration of Ukraine into the European banking system: cleaning, rebooting and Basel III. Banks \& bank systems. 2017. №. 12, № 4 (cont.). P. 163-174.

17. Regulation (EU) № 575/2013 of the European Parliament and of the Council of 26 June 2013 on prudential requirements for credit institutions and investment firms dated 30/09/2021. URL: http://data.europa.eu/eli/ $\mathrm{reg} / 2013 / 575 / \mathrm{oj}$

\section{References:}

1. Cabinet of Ministers of Ukraine. The Resolution dated 25.10.2017 № 1106 «On the implementation of the Association Agreement between the European Union and the European Atomic Energy Community and their Member States, of the one part, and Ukraine, of the other part». Available at: https://zakon.rada.gov.ua/laws/ show/1106-2017-n\#Text

2. Cabinet of Ministers of Ukraine. Monitoring system for the implementation of the Association Agreement between Ukraine and the EU. Information and analysis system «Pulse of the Agreement». Available at: http://pulse.eu-ua.org

3. National Bank of Ukraine. The decision by the Board of the National Bank of Ukraine «On approval of the plans for implementation of EU legislation for the implementation of the Association Agreement» dated 05.04.2017 № 207-pш.

4. National Bank of Ukraine (2021) Central Banks of Poland and Lithuania to Help NBU Implement EU-Ukraine Association Agreement. Available at: https://bank.gov.ua/en/news/all/tsentrobanki-polschi-ta-litvi-dopomojutnatsionalnomu-banku-ukrayini-implementuvati-ugodu-pro-asotsiatsiyu-mij-ukrayinoyu-ta-yes

5. National Bank of Ukraine (Kyiv, 2020) Strategy of Ukrainian financial sector development until 2025. Available at: https://bank.gov.ua/admin_uploads/article/Strategy_FS_2025_eng.pdf

6. Association Agreement between the European Union and the European Atomic Energy Community and their Member States, of the one part, and Ukraine, of the other part. Available at: https://zakon.rada.gov.ua/laws/ show/984_011\#Text

7. Razumkov Centre (Kyiv, 2020) Ukraine's sectoral integration into the EU: preconditions, prospects, challenges. Available at: https://razumkov.org.ua/uploads/article/2021_sektor_eu_eng.pdf

8. Directive 2013/36/EU of the European Parliament and of the Council of 26 June 2013 on access to the activity of credit institutions and the prudential supervision of credit institutions and investment firms dated 28/06/2021. Available at: http://data.europa.eu/eli/dir/2013/36/oj

9. European Commission (Brussels, 2021) Press release. Banking Package 2021: new EU rules to strengthen banks' resilience and better prepare for the future.

10. ING Bank (2021) Bank sector outlook 2022: Bracing for transformation. Available at: https:/think.ing.com/ articles/bank-sector-outlook-2022-bracing-for-transformation/

11. Intesa SanPaolo (2019). Basel III, Pillar 3. Disclosure as of 30 September 2019.

12. Moloney, N. (2014) European Banking Union: assessing its risks and resilience. Common Market Law Review, 51(6).

13. Proposal for a regulation of the European parliament and of the council on contestable and fair markets in the digital sector (Digital Markets Act). COM/2020/842 final dated 15.12.2020.

14. Proposal for a regulation of the European parliament and of the council on a Single Market for Digital Services (Digital Services Act) and amending Directive 2000/31/EC. COM/2020/825 final dated 15.12.2020.

15. Proposal for a regulation of the European parliament and of the council on Markets in Crypto-assets and amending Directive (EU) 2019/1937. COM/2020/593 final dated 24.09.2020.

16. Ramskyi, A., Loiko, V., Sobolieva-Tereshchenko, O., Loiko, D., \& Zharnikova, V. (2017) Integration of Ukraine into the European banking system: cleaning, rebooting and Basel III. Banks \& bank systems, no. 12, no. 4 (cont.), $163-174$.

17. Regulation (EU) № 575/2013 of the European Parliament and of the Council of 26 June 2013 on prudential requirements for credit institutions and investment firms dated 30/09/2021. Available at: http://data.europa.eu/ eli/reg/2013/575/oj 